OPEN ACCESS

Edited by:

John Frater,

University of Oxford, United Kingdom

Reviewed by:

Martyn Andrew French, University of Western Australia,

Australia

Ann Jones Hessell, Oregon Health \& Science University,

United States

*Correspondence:

Julià Blanco

jblanco@irsicaixa.es

Jorge Carrillo

jcarrillo@irsicaixa.es

Specialty section

This article was submitted to

Viral Immunology,

a section of the journal

Frontiers in Immunology

Received: 31 July 2018 Accepted: 02 October 2018 Published: 23 October 2018

Citation:

Carrillo J, Clotet B and Blanco J (2018) Antibodies and Antibody

Derivatives: New Partners in HIV Eradication Strategies.

Front. Immunol. 9:2429.

doi: 10.3389/fimmu.2018.02429

\section{Antibodies and Antibody Derivatives: New Partners in HIV Eradication Strategies}

\author{
Jorge Carrillo $^{1 *}$, Bonaventura Clotet ${ }^{1,2}$ and Julià Blanco ${ }^{1,2 *}$ \\ ${ }^{1}$ IrsiCaixa AIDS Research Institute, Institut de Recerca Germans Trias i Pujol, Badalona, Spain, ${ }^{2}$ Chair in AIDS and Related \\ IIInesses, Centre for Health and Social Care Research (CEES), Faculty of Medicine, Universitat de Vic - Universitat Central de \\ Catalunya, Vic, Spain
}

Promptly after primoinfection, HIV generates a pool of infected cells carrying transcriptionally silent integrated proviral DNA, the HIV-1 reservoir. These cells are not cleared by combined antiretroviral therapy (CART), and persist lifelong in treated HIV-infected individuals. Defining clinical strategies to eradicate the HIV reservoir and cure HIV-infected individuals is a major research field that requires a deep understanding of the mechanisms of seeding, maintenance and destruction of latently infected cells. Although CTL responses have been classically associated with the control of HIV replication, and hence with the size of HIV reservoir, broadly neutralizing antibodies (bNAbs) have emerged as new players in HIV cure strategies. Several reasons support this potential role: (i) over the last years a number of bNAbs with high potency and ability to cope with the extreme variability of HIV have been identified; (ii) antibodies not only block HIV replication but mediate effector functions that may contribute to the removal of infected cells and to boost immune responses against HIV; (iii) a series of new technologies have allowed for the in vitro design of improved antibodies with increased antiviral and effector functions. Recent studies in non-human primate models and in HIV-infected individuals have shown that treatment with recombinant bNAbs isolated from HIV-infected individuals is safe and may have a beneficial effect both on the seeding of the HIV reservoir and on the inhibition of HIV replication. These promising data and the development of antibody technology have paved the way for treating HIV infection with engineered monoclonal antibodies with high potency of neutralization, wide coverage of HIV diversity, extended plasma half-life in vivo and improved effector functions. The exciting effects of these newly designed antibodies in vivo, either alone or in combination with other cure strategies (latency reversing agents or therapeutic vaccines), open a new hope in HIV eradication.

Keywords: broadly neutralizing antibodies, HIV persistence, effector functions, HIV reservoir, NK cells, ADCC

\section{HIV PERSISTENCE: THE SUCCESS AND THE FAILURE OR ANTIRETROVIRAL THERAPY}

HIV, as other retroviruses, requires integration of the proviral genome into host cells to allow for transcription of viral genes and completion of the viral life cycle (1). Both events, integration and further transcription of integrated proviral genomes are strongly dependent on the activation status of target $\mathrm{CD}^{+} \mathrm{T}$ cells. Highly activated cells efficiently integrate and replicate HIV, while resting 
cells hardly support viral integration and show low or null transcriptional activity (2). Therefore, upon infection, a pool of latently infected cells bearing silent HIV proviral sequences, the HIV reservoir, is formed either by the ability of HIV to overcome integration restrictions in resting cells (3) or by the contraction of immune responses that allows some HIV-infected activated cells to return to a resting status, silencing viral transcription (4).

Current treatment of HIV infection, the combination antiretroviral therapy (cART), is mostly based on an array of inhibitors of several viral enzymes (reverse transcriptase, protease or integrase) and is extremely effective at blocking HIV replication, leading to a sustained suppression of plasma viremia at least below the limit of detection of standard assays (5). However, the persistence of the HIV reservoir and its spontaneous activation rapidly resume viral replication after treatment interruption. Recent data describing treatment interruption of very early treated individuals (Fiebig I) shows that the HIV reservoir is rapidly established after primoinfection (6). Although the HIV reservoir is relatively small in size, ranging from 1 to 100 latently infected cells per million of $\mathrm{CD}^{+}{ }^{+} \mathrm{T}$ cells, cells, it may encompass long-lived cells, such as resting memory $\mathrm{CD} 4^{+} \mathrm{T}$ cells or macrophages $(7,8)$, The main consequence of this fact is that the pool of latently infected cells in treated HIV-infected individuals shows a slow decay overtime. The half-life of the HIV reservoir has been calculated in 3.75 years and therefore its natural eradication would require 60 years of continuous cART treatment (2). Several attempts to accelerate reservoir decay by combining new and more potent drugs in optimal cART regimens have shown some impact on viral and immune dynamics but failed to show a positive effect on the HIV reservoir decay rate (913). Consequently, HIV-infected individuals have to manage life-long coexistence with HIV, with therapy, and with their associated complications, such as chronic immune activation and inflammation, and drug toxicities. Ultimately, these effects may result in accelerated immunosenescence and aging (14) that associates with higher incidence of co-morbidities and mortality compared to non-infected individuals (8). Therefore, there is an emergent interest in developing safe and affordable curative strategies that would eliminate the need of lifelong therapy in HIV-infected individuals, either by completely eradicating the viral reservoir (sterilizing cure) or by empowering the immune control of HIV-replication (functional cure).

\section{DYNAMICS OF HIV RESERVOIR UNDER CART: CLUES FOR CURE}

The complete eradication of the pool of latently infected cells in HIV-infected individuals has been approached from molecular, pharmacological and immune perspectives. Molecular approaches are based on sequence specific CRISPR-CAS-based tools that may allow for the excision or reactivation of proviral DNA from latently infected cells; however, their clinical efficacy and potential off-target effects are not yet known (15). In contrast, more classical pharmacological and immunological strategies have reached human trials and have been tested in

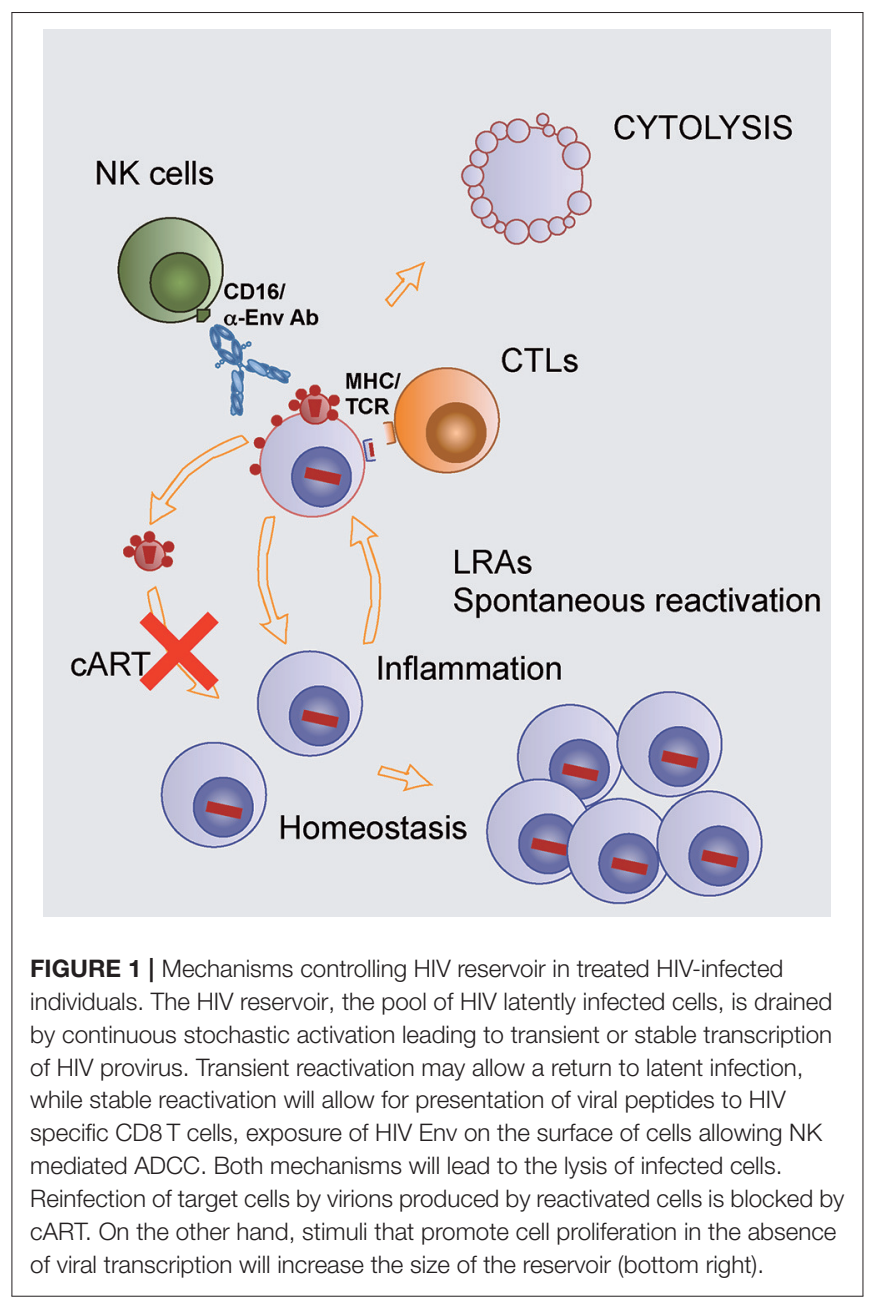

HIV-infected individuals. All these approaches are designed to perturb the long-lived HIV reservoir (Figure 1). Although the pool of latently infected cells is stable overtime, it is not static. On the one hand, homeostatic control of $\mathrm{T}$ cells and inflammatory environment may induce the proliferation of latently infected cells $(16,17)$. When this proliferation occurs in the absence of HIV transcription, it results in an increase in the HIV reservoir size, this is the case of HIV-infected individuals treated with IL7 (18). Furthermore, clonal expansion of latently infected cells driven by antigen specificity or specific integration sites has also been described in HIV-infected individuals $(19,20)$.

On the other hand, HIV transcription in latently infected cells can become spontaneously and stochastically activated by different stimuli, also including specific antigens or nonspecific inflammatory signals, that reverse epigenetic silencing of HIV transcription (21). Once reactivated, cells will produce viral particles whose infectivity will be blocked by cART (Figure 1), and will expose viral antigens, both mature envelope glycoproteins (Env) on the cell surface and viral peptides presented by MHC will allow the immune system to recognize the reactivated cell before a potential return to a resting status or cytolysis mediated by cytopathic effects of HIV 
proteins (Figure 1). Immune recognition will accelerate the lytic process either by HIV-specific CD8+ cytotoxic T cells (CTL) or by CD16+ NK cells sensing antibodies bound to Env (Figure 1). However, the extent of both CTL and NK mediated cell lysis in HIV-infected individuals could be incomplete. In the case of CTL, a broad and properly stimulated response seems to be required to overcome the dominance of escape mutations and the inherent resistance of reactivated cells to CTL mediated killing (22-24). Regarding antibodies, the main limitation is the lack of good-quality antibodies against HIV Env and the potential perturbation of both B and NK cell functions induced by $\operatorname{HIV}$ infection $(25,26)$. Despite these limitations, indirect evidence link both CTL and NK cell function to the reservoir size in HIV-infected individuals (27-29).

Irrespective of the cytolytic mechanisms, the combination of reactivation (kick) and lysis (kill) will result in a continuous reduction of the HIV reservoir size. Therefore, kick-and-kill strategies are paradigmatic in the purge of the HIV reservoir (30). Optimization of kick is exploring a wide range of latency reversing agents (LRA). Several compounds acting at different levels of the control of HIV transcription, including histone deacetylase (HDAC) inhibitors and Toll-like receptors (TLR) agonists, have been tested in in vitro assays or in in vivo animal models to screen them for potential use in humans (31). Certainly, some of them have reached clinical trials in HIV-infected individuals, such as the HDAC inhibitors valproic acid, disulfiram, vorinostat, panobinostat, or romidepsin and the protein kinase $\mathrm{C}$ modulator briostatin (32-38). These trials yielded, at best, promising results in terms of HIV reactivation, showing transient increases in cell associated HIV RNA levels; however, no changes in HIV reservoir size were observed. Taken together, these data suggest that a better killing step is necessary to impact on the reservoir size. Thus, enabling the immune system to rapidly kill kicked cells seems to be a necessary step in cure strategies. Although, CTL based strategies, namely therapeutic vaccination aimed at inducing new CTL specificities, is an active field (39); antibody-based therapies have emerged as a new and powerful tool (40). Some reasons that explain the renewed interest in antibodies are the isolation of broad and highly potent anti-HIV antibodies, the demonstration of their safety and antiviral activity in vivo and the idea that antibodies display immunomodulatory activities beyond the antiviral activity.

\section{ANTIBODIES, ANTIVIRAL AGENTS BEYOND ART}

Antibodies share with cART the capacity to block HIV replication, in the case of antibodies by their ability to inhibit HIV entry, also known as neutralizing activity. Direct antiviral or neutralizing activity depends on the variable region of the antibody that is defined by the N-terminal domains of the heavy and light chains of the molecule (Figure 2). The HIV Env is the sole viral protein exposed on virions and productively infected cells and is therefore the target for HIV neutralizing antibodies
(41). Env is a heterotrimer of gp120 and gp41 subunits, with a high structural complexity, sequence variation and plasticity (42, 43). Despite this, several potent and broad neutralizing antibodies (bNAbs) have been identified that bind to relatively conserved and functionally relevant regions of Env. These epitopes, called vulnerability sites, are the CD4 binding site, the external V2 or the V3 loops in gp120, the gp120/gp41 interface and the fusion peptide or the membrane proximal external region (MPER) of gp41 (Figure 2) $(42,44,45)$.

Unlike cART, antibodies can be considered polyfunctional molecules as they can mediate several antiviral functions combining direct blockade of viral infectivity (neutralization) and indirect immunological mechanisms (effector functions) that require the recruitment and activation of immune cells, such as NK cells or macrophages. Effector functions depend on the interaction of the fragment crystallizable $(\mathrm{Fc})$ region of antibodies and specific Fc-Receptors (FcRs) differentially expressed on the surface of immune cells. The Fc domain is defined by the heavy chain of antibodies that also defines the isotype (46). For the main antibody isotype, $\operatorname{IgG}$, four subtypes have been described, among them IgG1 and IgG3 are the most active mediating effector functions in viral infections (47). In this way, IgG1 and IgG3 can act as a "linker," facilitating the interaction between immune-effector cells and virions or infected cells and promoting their elimination (Figure 2). Among the functions assigned to the Fc portion of antibodies, complementmediated lysis, antibody-dependent cellular cytotoxicity (ADCC) and Antibody-dependent phagocytosis (ADCP) are highlighted because they are highly effective in killing and removing infected cells, thereby contributing to antiviral functions. Importantly, interactions of antigen bound antibodies with immune cells also act as a danger signal and are part of the communication network of the immune system to improve immune responses at the local or systemic level. One of the most relevant examples is the activation of conventional and plasmacitoid dendritic cells (DC) by immunocomplexes (IC). Such IC recognition leads to enhanced antigen uptake and presentation, allowing induction of stronger humoral and cellular antiviral immune responses, reviewed in (48).

Although Fc-mediated effector functions need for the antibody to recognize the antigen on the surface of infected cells, they are independent of the neutralizing potential. Therefore, both neutralizing and non-neutralizing antibodies could be effective mediating Fc-dependent antiviral functions. The best example is provided by the RV144 trial (49). In this trial involving more than 1,6000 individuals, a combination of Env immunogens failed to elicit a strong cross-neutralizing humoral response, but induced antibodies with ADCC activity that correlated with protection in individuals showing low IgA response $(50,51)$. Interestingly, Hessell et al. showed that the protective role of the IgG1b12 against SHIV acquisition observed in non-human primate (NHP) models was associated with the $\mathrm{Fc}-\mathrm{FcR}$ interaction but not with complement activation (52). Therefore, these results suggested that the neutralizing capacity of the antibody is not enough to confer protection against HIV and probably the combination of both neutralization and Fc-dependent effector function, such as ADCC or ADCP are 


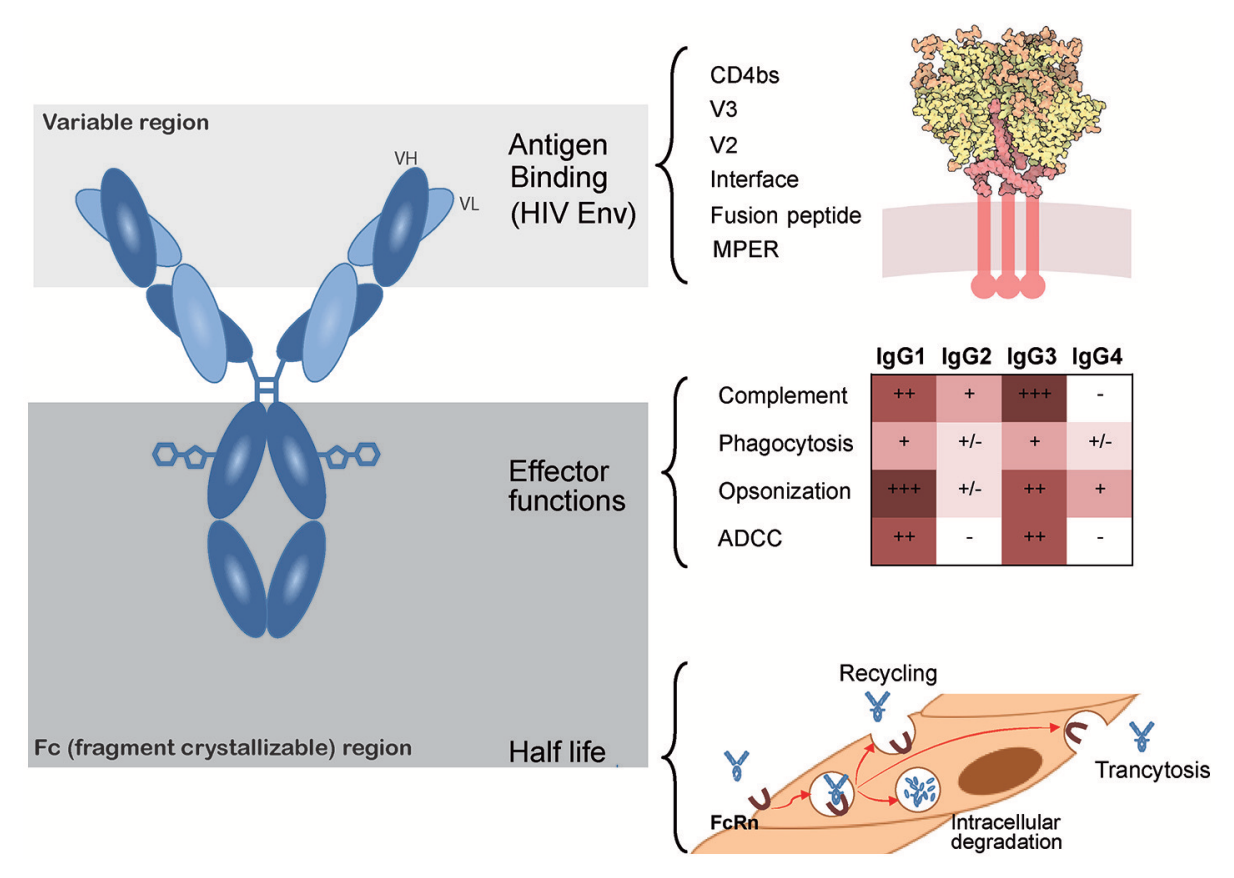

FIGURE 2 | Main antibody features. Antibodies are glycosylated heterodimeric molecules showing a variable region in both light and heavy chains that determine antigen binding. For bNAbs, antigen binding is located on the indicated vulnerability sites of the HIV Env glycoprotein formed by heterotrimers of gp120 (yellow) and gp41 (red in the upper right panel). The crystallizable fragment of the antibodies (FC) encompasses all constant regions and is responsible for the effector functions. Different antibody subtypes show selective effector functions (color coded displayed in the middle right panel). Furthermore, the Fc region also regulates plasma half-life of antibodies, as they are continuously recycled, degraded or transcytosed by endothelial cells through neonatal Fc receptors (FcRn, lower right panel). HIV Env picture (http://www.rcsb.org/pdb/101/motm.do?momID=169) is from David S. Goodsell and the RCSB PDB under Creative Commons.

required. Accordingly, bNAbs whose Fc portion was modified to increase binding to activating $\mathrm{FcR}$ showed an improved protective capacity when they were assayed in humanized mice models (53).

In addition to the effector functions described above, the Fcportion of IgGs is also responsible for the interaction with the neonatal Fc receptor (FcRn) widely expressed on endothelial cells. The interaction with this receptor plays a major role in the control of the plasma half-life of antibodies by regulating the acidic degradation of IgGs into the lysosome of endothelial cells (54). The mechanism is based on the $\mathrm{pH}$ dependence of the binding of antibodies to FcRn. Binding shows higher affinity at $\mathrm{pH} 6$, which is the endosomal $\mathrm{pH}$, and low affinity at neutral $\mathrm{pH}$ (extracellular). This fact enables antibodies taken up by endothelial cells to remain bound to the FcRn and recycle to the cell surface, avoiding the acidic degradation. Once the antibody/FcRn complex reaches the extracellular neutral $\mathrm{pH}$ compartment, antibodies are released. Importantly, besides regulating plasma half-life, this recycling process also modulates antibody transcytosis to tissues (55). Taking advantage of this mechanism, a modified VRC01 antibody (VRC01-LS), which showed an improved binding to the FcRn at $\mathrm{pH}=6$, provided superior protective capacity than the wild type version in rhesus macaques, not only by increasing its in vivo halflife but also by reaching a higher concentration at mucosal level (56).
Indirectly, antibodies might also contribute to improve the CTL response against HIV-1. The treatment of rhesus macaques with a combination of 3BNC117 and 10-1074 antibodies very early after SHIV infection, helps to control the infection by a mechanism in which CD8+T cells seem to be fundamental (57). Nevertheless, it is possible that antibodies contribute to promote the $\mathrm{T}$ cell response by improving the antigen presentation capacity of DCs. As mentioned above, IC composed of antibodies, virions and probably complement, can be efficiently captured by DCs, via FcR, processed and presented to T cells, improving the cellular response against viral antigens (48). This process seems to be highly dependent on timing, since this effect has not been observed when antibodies were administered before infection or during the chronic phase, and, probably might also depend on the neutralizing capacity and isotype of the antibody used.

In summary, antibodies show a wide range of antiviral activities that make them highly attractive as anti-HIV-1 agents. They can reduce viral load and kill infected cells by recruiting and activating effector immune cells. Moreover, they can be long-acting and can collaborate with the immune system improving different mechanisms that can control HIV-1 infection. Considering that these mechanism depend on specific regions within the antibody molecule, these regions can be modified to improve the global activity, making antibodies more potent or with a better in vivo pharmacokinetic profile. However, 
the contribution of antibodies to the removal of the HIV reservoir is still poorly defined.

\section{Isolation of bNAbs From HIV-Infected Individuals: Selecting the Best Candidates}

Probably the major limitation of antibodies in their continuous race against $\mathrm{HIV}$ is the structural complexity and the unprecedented variability of the HIV envelope glycoprotein (41). Although the humoral response against HIV Env is strong, most of anti-HIV Env antibodies fail to bind to complex trimeric epitopes and those recognizing the trimer usually are strain specific. Only a small proportion of anti-Env antibodies are bNAbs, i.e., block a large number of Env variants (58).

The isolation of bNAbs to inform on vaccine design and protective mechanisms has been a challenge over the last years. Initial efforts identified the anti-CD4bs antibody IgGb12, the anti-glycan 2G12 and the anti-MPER antibodies 2F5 and 4E10 as neutralizing antibodies. However, their potency was low (in the microgram/ml range) and the breadth limited $(59,60)$. New molecular and cellular screening technologies $(61,62)$ and large efforts by several laboratories have extremely helped to identify newer, broader, and more potent antibodies (40). Current bNAbs target vulnerability sites of HIV Env, show antiviral activity in the $\mathrm{ng} / \mathrm{ml}$ range and cover a wide range of HIV isolates from different clades. In general, anti-CD4bs antibodies, such as VRC01, 3BNC117, VRC07, or N6 show intermediate potency and high breadth ( $>80 \%$ of a panel of 200 isolates), being the N6 antibody almost panneutralizing (63-66). In contrast, antibodies directed against the V2 loop, such as PG9 or PG16 (67), or against the V3 loop, such as 10-1074 or PGT121 (68) show higher potency but lower coverage, being able to neutralize roughly a $60 \%$ of circulating HIV isolates. The case of the anti-MPER antibody 10E8 is also relevant, it shows the widest coverage but has a limited potency (65).

The excellent combination of potency and coverage of recently isolated bNAbs have allowed for their clinical development. Over the last years, VRC01, 10-1074, 3BNC117, VRC07 or their combinations have reached clinical trials in humans (69-72), opening the door for antibody-based therapies to treat and cure HIV infection (40).

\section{Engineered Antibodies}

Despite the remarkable potency of bNAbs isolated from HIVinfected individuals, they show several limitations to become referent drugs in HIV treatment. Firstly, the number of antibodies is still low and there is a need for more potent antibodies particularly for some specificities, such as the MPER or the new vulnerability sites. Secondly, the number of isolates neutralized by some bNAbs is still low, and therefore combination strategies should be envisaged, increasing the development and production costs. For this reason, a wide range of modifications have been made to naturally occurring antibodies in order to increase their potency, coverage or pharmacodynamics behavior (40). The technologies to modify antibodies have grown as immunotherapies against several human diseases, such as cancer or autoimmune diseases emerged (73). Current technologies encompass modifications in the variable or the Fc regions of antibodies to modulate their antigen binding and their effector functions, respectively.

Several of those modifications have been applied to anti-HIV bNAbs. Huang et al. designed an asymmetric bispecific antibody containing the variable regions of an anti-CD4bs antibody and the 10E8 anti-MPER bNAb. This construction showed almost panneutralizing activity with a median IC50 of $2 \mathrm{ng} / \mathrm{ml}$ (74). Similarly, Bournazos et al. designed a flexible bispecific IgG3 antibody containing the 3BNC117 and the PGT135 variable regions (75). Other strategies involve the addition of specificities at the C-terminal end of the IgG. In this regard, Gardner et al. added a peptide that binds to the coreceptor binding site at the end of a CD4-IgG1 fusion protein resulting in the molecule eCD4-Ig that show also panneutralizing activity with a median IC50 in the $\mathrm{ng} / \mathrm{ml}$ range (76) and maintain ADCC activity (77). Further modifications in antibody specificity involve the addition of a second variable region to the antibody arms, if this strategy is combined with an asymmetric chain assembly the result is a trispecific antibody. Such a molecule has been recently designed by combining the variable regions of the VRC01, the PGDM1400, and the 10E8 antibodies yielding a highly active and virtually panneutralizing molecule (78). Finally, increased neutralizing activity can be also achieved by introducing small modifications in the variable regions of antibodies; this is the case of antibody VRC07-523, an antibody with improved profile designed by computational bioinformatics, and structure-guided design (64), or the antibody NIH45-46 ${ }^{\mathrm{G} 54 \mathrm{~W}}$ that shows improved neutralization than its wild type counterpart (79). All above described engineered antibodies have been tested in animal models with excellent prophylactic results.

Modifications to the Fc moiety of antibodies have been also implemented into anti-HIV bNAbs. It is well known that glycosylation of the Asn297 residue in IgG1 is required for binding to CD16 and ADCC activity, and that removal of a fucose residue in the sugar chain increases binding to CD16 and ADCC activity of 2G12 and PG9 antibodies (80, 81). These modifications have been also applied to newly designed multivalent antibodies to improve ADCC-mediated removal of HIV-infected cells (82). However, the most common modification of the $\mathrm{Fc}$ is related to the binding to FcRn. Increasing the affinity of IgG for FcRn at $\mathrm{pH} 6$ reduces lysosomal degradation of IgG by endothelial cells and extends IgG plasma half-life. For instance, the M428L and the N434S mutations in Fc, conferring an improved binding profile to the FCRn, have been introduced into the VRC01, the 101074 and the 3BNC117 antibodies, resulting in increased in vivo plasma half-life (83) and also reaching a higher concentration at mucosal level (56).

Alternatively, the Fc portion of antibodies can be completely removed. The resulting small molecules called dual-affinity re-targeting proteins (DART) are composed of two antigenbinding variable regions linked by a short sequence allowing the recognition of two different antigens (84). When one specificity is directed against the HIV Env and the other against CD16 or CD3, the resulting molecules may serve as a linker between HIVinfected cells and effector cells, NK or CTL, respectively (40). These molecules, despite their short plasma half-life $(85,86)$ may facilitate the removal of HIV-infected cells, exploiting the full 
TABLE 1 | Latest Human Clinical Trials Involving bNAbs.

\begin{tabular}{|c|c|c|c|c|}
\hline Antibody(ies) & $\begin{array}{l}\text { Target } \\
\text { population }\end{array}$ & Endpoint & Dose $^{a}$ & References \\
\hline $\begin{array}{l}2 \mathrm{G} 12+2 \mathrm{~F} 5 \\
+4 \mathrm{E} 10\end{array}$ & $\begin{array}{l}\text { HIV infected } \\
\text { CART } \\
\text { interruption }\end{array}$ & VL rebound & $\begin{array}{l}30 \mathrm{mg} / \mathrm{Kg} \\
\mathrm{IV}\end{array}$ & (84) \\
\hline VRC01 & $\begin{array}{l}\text { HIV infected } \\
\text { Untreated }\end{array}$ & VL decay & $\begin{array}{l}\text { Up to } 40 \\
\mathrm{mg} / \mathrm{Kg} \\
\mathrm{IV} / \mathrm{SC}\end{array}$ & (68) \\
\hline 3BNC117 & $\begin{array}{l}\text { HIV infected } \\
\text { Untreated }\end{array}$ & VL decay & $\begin{array}{l}\text { Up to } 30 \\
\mathrm{mg} / \mathrm{Kg} \\
\mathrm{IV}\end{array}$ & (69) \\
\hline 10-1074 & $\begin{array}{l}\text { HIV infected } \\
\text { Untreated }\end{array}$ & VL decay & $\begin{array}{l}\text { Up to } 30 \\
\mathrm{mg} / \mathrm{Kg} \\
\mathrm{IV}\end{array}$ & (70) \\
\hline VRC01LS & $\begin{array}{l}\text { HIV } \\
\text { uninfected }\end{array}$ & Safety & $\begin{array}{l}\text { Up to } 40 \\
\mathrm{mg} / \mathrm{Kg} \\
\mathrm{IV} / \mathrm{SC}\end{array}$ & (91) \\
\hline $\begin{array}{l}\text { VRCO7- } \\
\text { 532LS }\end{array}$ & $\begin{array}{l}\text { HIV } \\
\text { uninfected }\end{array}$ & Safety & $\begin{array}{l}\text { Up to } 40 \\
\mathrm{mg} / \mathrm{Kg} \\
\mathrm{IV} / \mathrm{SC}\end{array}$ & (92) \\
\hline $\begin{array}{l}\text { 10-1074 + } \\
\text { 3BNC117 }\end{array}$ & $\begin{array}{l}\text { HIV } \\
\text { uninfected } \\
\text { untreated }\end{array}$ & Safety & $\begin{array}{l}\text { Up to } 30 \\
\mathrm{mg} / \mathrm{Kg} \\
\mathrm{IV}\end{array}$ & (93) \\
\hline
\end{tabular}

a $V$, intravenous; SC, subcutaneous.

repertoire of CD8 $+\mathrm{T}$ cells, as antigen specificity is not provided by the effector cell, but by the molecule.

\section{ANTIBODIES IN HIV THERAPY AND THE CONTROL OF HIV RESERVOIR}

Immunotherapies using hyperimmune plasma were assessed in HIV-infected individuals before cART development in early years of HIV pandemics with disappointing results (87). Some years later, the available recombinant antibodies at that moment, the anti-glycan 2G12 and the anti-MPER 2F5 and 4E10 mAbs, reached clinical trials. All antibodies were safe in HIV-infected individuals $(88,89)$, although clinical effect was limited as shown by Trkola et al (90). These authors used a combination of the above-mentioned antibodies to treat HIV-infected individuals undergoing interruption of cART (Table 1). The effect on viral rebound was minimal, only observed in two of eight individuals and evidenced a partial activity of the antibody 2G12 (90). Despite the lack of clinical benefit, these trials demonstrated that treatment with anti-HIV antibodies was safe and paved the way for future treatments with newer and more potent antibodies.

\section{NHP Models}

The isolation and development of bNAbs has mostly focused on the prophylactic activity, generating a plethora of work that demonstrates the efficacy of antibodies delivered as passive infusions or though gene therapy to protect animals from HIV acquisition, excellently reviewed in Pegu et al. (94). The first clear evidence of a therapeutic activity of antibodies came from humanized mice models (95). Klein et al. infected immunodeficient mice humanized with human CD34+ cells with the HIV isolate YU-2. Three weeks after infection animals were treated with monotherapy with the antibodies 3BC176, PG16, NIH45-46 G54W, PGT128, or 10-1074. The effect of monotherapy on viral load (VL) was minimal, while the combination of three antibodies had some effect and the combination of all five antibodies achieved a sustained reduction of VL. Thus, combinations of potent monoclonal antibodies could effectively control HIV-1 replication at least in mouse models. This observation was relevant as the efficacy of antibodies against cell-to-cell HIV transmission, one of the most efficient in vivo mechanisms of HIV spread, was under discussion at that time (91, 96-98).

Further evidence of therapeutic activity of antibodies came from two different experiments in SHIV-infected Rhesus macaques $(63,92)$. Barouch et al. demonstrated that PGT121 administration to SHIV SF162P3-infected Rhesus resulted in a rapid decline of viral replication that was dependent on the level of VL at baseline, and was sustained for those animals with lower VL (92). Similarly, Shingai et al. treated SHIV AD8-infected rhesus macaques with the anti CD4bs antibody $3 \mathrm{BNC} 117$ or the anti-V3 antibody 10-1074 either as monotherapy or in combination. In monotherapy, the 10-1074 antibody caused a transient (4-7 days) undetectability of VL followed by virus rebound and appearance of mutations in the virus that confer resistance to the antibody. When administered together, 3BNC117 and 10-1074 induced a 3-5 weeks sustained suppression of VL without evidence of emergence of resistant viruses (63).

Despite these promising data, the effect of bNAbs on the HIV reservoir is still elusive. Initial work on humanized mice described an impact of bNAbs on HIV-infected cells by a mechanism related to their Fc effector functions $(53,93,99)$. However, the most exciting results suggesting an effect of antibodies on the HIV reservoir have been recently generated in two papers demonstrating a clear long-term effect of antibody treatment in NHP $(57,100)$. Borducchi et al. treated SHIV SF162P3-infected rhesus 1 week after SHIV exposure with serial doses of PG121 antibody, the LRA GS-9620 (a TLR7 agonist) or a combination of both. Treatment was concomitant to cART, and after immunotherapy, cART was maintained for more than 2 years. After cART interruption all control animal showed rapid rebound of VL. TLR7 agonist monotherapy had a modest effect on viral rebound, while antibody treatment and particularly the combination of antibody and TLR7 agonist delayed or prevented VL rebound in most animals. Interestingly, all animals treated with combination therapy showed spontaneous control of viremia after cART cessation (100). Similarly, Nishimura et al treated SHIVAD8-EO infected Rhesus with a combination of 3BNC117 and 10-1074 bNAbs during acute infection. The effect of the treatment was a long-lasting control of HIV replication in roughly half of animals (six of thirteen) that seems to be related to an enhanced CTL mediated control of viral replication (57), suggesting a not yet defined immunomodulatory effect of antibodies in the course of HIV infection, probably related to the enhancement of immune responses by ICs captured by 
DCs reported in other viral infections (48) Although, these experimental designs are hard to replicate in humans due to the very early therapy schedule, these results show for the first time the potential of bNAb immunotherapy in HIV cure (either sterilizing or functional).

\section{Human Trials}

The progresses in bNAb-based therapy in humans are slow due to regulatory constraints. However, besides early trials using firstgeneration antibodies (90), several second-generation bNAbs have reached human clinical trials in passive administration assays. A summary of the most recent trials is shown in Table 1. The anti-CD4bs antibodies VRC01, VRC07-532LS, and 3BNC117 and the anti-V3 loop antibody 10-1074 were tested in HIV uninfected individuals demonstrating to be safe and well tolerated (101). Pharmacokinetics was variable among the different antibodies tested, showing a plasma half-life close to 15 days, as expected for a therapeutic IgG. Interestingly, the VRC01LS antibody, a derivative of VRC01 containing the M428L and the N434S mutations in the Fc showed increase plasma half-life (71 \pm 18 days) and was also safe in a Phase I trial (102). Similar results have been reported for the VRC07532LS antibody containing a similar set of mutations in the Fc and showing also an extended half-life of $33 \pm 18$ days (103). Furthermore, combination of 3BNC117 and 10-1074 does not seem to alter their individual pharmacokinetics or safety profile (104).

VRC01, 3BNC117 and 10-1074 antibodies have been also tested in untreated HIV-infected individuals (69-71). The behavior of all antibodies was similar, showing the weaknesses and strengths of antibody monotherapy. Treatment led to a reduction of VL in most of individuals (ranging from a 1.1 to 1.8 logs) with more sustained suppression in individuals with lower baseline viremia. However, in some patients the antibody had no effect on VL, due to the presence of viral variants that were insensitive to neutralization activity (resistant viruses). Interestingly, most individuals that transiently reduced VL showed in the rebounded virus mutations conferring reduced sensitivity to the therapeutic antibody, suggesting rapid development of HIV resistance (69-71). Furthermore, due to active antigen removal, the plasma half-life of antibodies was shorter than in HIV uninfected individuals (69-71). In addition to these expected data, antibody treatment also revealed further relevant information. The passively administered antibody 3BNC177 altered the kinetics of HIV-1 suppression in infected individuals, suggesting an active effect of the antibody on infected cell clearance. Consistent with data from animal models, the mechanism would require $\mathrm{Fc} \gamma$ receptor engagement (105). Moreover, this antibody also seems to significantly improve neutralizing responses to tier 2 viruses in most study participants, suggesting beneficial immunomodulatory properties as described in other animal models (48). In contrast, treatment with VRC01 antibody had no impact on the size of HIV reservoirs in cART treated HIV-infected individuals at least 4 weeks after two antibody infusions (69).

\section{ANTIBODIES IN PREVENTION STRATEGIES: TARGETING SEXUAL AND VERTICAL TRANSMISSION}

Besides the potential role in cure intervention, bNAbs may also be useful in preventative strategies further contributing to control and eradicate the HIV pandemic. Complementing the therapeutic use of antibodies, human trials have been started to determine the efficacy of the antibody VRC01 in protecting HIV uninfected individuals at risk of HIV acquisition. A large study in men who have sex with men (MSM) in US and women in Africa (the AMP study) is currently conducted $(106,107)$ to test antibody-mediated protection of sexual HIV transmission. However, one of the most attractive fields for the prophylactic use of antibodies is mother to child transmission (MTCT), excellently reviewed in (108).

The evolution of the prophylactic use of antibodies has paralleled the therapeutic application. Pioneer work involved purified immunoglobulins from HIV serum to block MTCT by treating HIV-1-infected pregnant women showing safety but a complete lack of efficacy $(109,110)$. Additional studies confirmed these early result (111). Again, the isolation of secondgeneration bNAbs, along with the recent data obtained in NHP and humans, has renewed the interest on the use of nNAbs to block MTCT. Although there is profuse information on the excellent prophylactic activity of bNAbs in adult uninfected rhesus macaques challenged with HIV (94), specific studies on animal models of MTCT are more recent. Hessell et al. inoculated orally 1-month-old rhesus macaques with SHIV and treated them subcutaneously with VRC07 and PGT121 1 day after virus exposure. All treated animals showed no SHIV or anti-SHIV T cell responses in blood or tissues at necropsy, and importantly no virus emerged after CD8 T cell depletion (112), suggesting that early passive immunotherapy can eliminate early viral foci and thereby prevent the establishment of viral reservoirs in newborns.

These preclinical data have fostered the clinical use of bNAbs in prevention of MTCT in the hallmark the International Maternal/Adolescent AIDS Clinical Trials Network (IMPAACT). Indeed, the P1112 study is currently ongoing and evaluates the safety and PK analysis of the antibody VRC01 in HIV-exposed newborns and will also include the VRC01-LS in one of the arms (113). Moreover, the 2008 study is also being conducted; this is Phase I/II study that uses VRC01 in combination with cART to analyze the effect on the clearance of HIV-1-infected cells in infants. The data from both studies will inform on potential benefits of antibodies to reduce MTCT and the possibility to expand bNAb-based eradication strategies to infants.

\section{FUTURE CLINICAL PERSPECTIVES AND REMARKS}

Preliminary data on the therapeutic use of bNAbs isolated from HIV-infected individuals suggests a strong potential in HIV cure strategies. However, their clinical use is limited by the availability of antibodies, the antiviral potency and the preexisting resistances. To overcome these limitations, a 
large array of synthetic multifunctional antibodies with higher potency, breadth of neutralization and tailored effector functions (including CTL mediated killing) are under development to feed the pipeline of antibody-based therapies and to improve our current arsenal of anti-HIV drugs. It should be noted that those newly designed antibodies show a potency equivalent to the most active antiretroviral ( $\mathrm{IC}_{50}$ in the $\mathrm{pM}$ range), offer minimal natural resistance (and given their multifunctional mechanism of action an anticipated high genetic barrier) and a wide range of immunological effect, most of them not yet completely understood.

The clinical setting for antibody treatment is also an open field. A reduction of the HIV reservor by passive antibody administration to chronic HIV-infected individuals would be desirable, but could be incomplete. Despite preliminary promising data, bNAbs will probably require combination with LRAs or therapeutic vaccines to eradicate HIV. Early treatment is probably a more promising scenario. Replicating excellent data obtained by early treatment of NHP in humans would speed the implementation of this type of therapies. Although implementation in adults is complex due to the challenging detection of early infection, a promising future is envisaged in MTCT settings. New technologies will also help bNAb therapy.

\section{REFERENCES}

1. Furtado MR, Callaway DS, Phair JP, Kunstman KJ, Stanton JL, Macken CA, et al. Persistence of HIV-1 transcription in peripheral-blood mononuclear cells in patients receiving potent antiretroviral therapy. N Engl J Med. (1999) 340:1614-22. doi: 10.1056/NEJM199905273402102

2. Pierson T, McArthur J, Siliciano RF. Reservoirs for HIV-1: mechanisms for viral persistence in the presence of antiviral immune responses and antiretroviral therapy. Annu Rev Immunol. (2000) 18:665-708. doi: 10.1146/annurev.immunol.18.1.665

3. Saleh S, Solomon A, Wightman F, Xhilaga M, Cameron PU, Lewin SR. CCR7 ligands CCL19 and CCL21 increase permissiveness of resting memory CD4+ T cells to HIV-1 infection: a novel model of HIV-1 latency. Blood (2007) 110:4161-4. doi: 10.1182/blood-2007-06-097907

4. Han Y, Wind-Rotolo M, Yang H-C, Siliciano JD, Siliciano RF. Experimental approaches to the study of HIV-1 latency. Nat Rev Microbiol. (2007) 5:95-106. doi: 10.1038/nrmicro1580

5. Massanella M, Martinez-Picado J, Blanco J. Attacking the HIV Reservoir from the Immune and Viral Perspective. Curr HIV/AIDS Rep. (2013) 10:33-41. doi: 10.1007/s11904-012-0150-8

6. Henrich TJ, Hatano H, Bacon O, Hogan LE, Rutishauser R, Hill A, et al. HIV1 persistence following extremely early initiation of antiretroviral therapy (ART) during acute HIV-1 infection: an observational study. PLoS Med. (2017) 14:e1002417. doi: 10.1371/journal.pmed.1002417

7. Murray AJ, Kwon KJ, Farber DL, Siliciano RF. The latent reservoir for HIV1: how immunologic memory and clonal expansion contribute to HIV-1 persistence. J Immunol. (2016) 197:407-17. doi: 10.4049/jimmunol.1600343

8. Sattentau QJ, Stevenson M. Macrophages and HIV-1: an unhealthy constellation. Cell Host Microbe (2016) 19:304-10. doi: 10.1016/j.chom.2016.02.013

9. Puertas MC, Gómez-Mora E, Santos JR, Moltó J, Urrea V, Morón-López S, et al. Impact of intensification with raltegravir on HIV-1-infected individuals receiving monotherapy with boosted PIs. J Antimicrob Chemother. (2018) 73:1940-8. doi: 10.1093/jac/dky106

10. Puertas MC, Massanella M, Llibre JM, Ballestero M, Buzon MJ, Ouchi D, et al. Intensification of a raltegravir-based regimen with maraviroc in early HIV-1 infection. AIDS (2014) 28:325-34. doi: 10.1097/QAD.0000000000000066
Passive administration can be replaced by gene therapy using Adeno-Associated Viruses (AAV), a strategy that has provided excellent results in NHP and that is currently being tested in humans $(76,114-116)$.

\section{AUTHOR CONTRIBUTIONS}

JB and JC drafted the manuscript. JC and BC reviewed the manuscript and made substantial, direct, and intellectual contributions to the work. All authors approved it for publication.

\section{FUNDING}

The work in JB's lab is supported by the HIVACAT Program, the CERCA Program (Generalitat de Catalunya), the Fondo de Investigaciones Sanitarias, and FEDER Fondo Europeo de Desarrollo Regional through the Spanish AIDS network Red Temática Cooperativa de Investigación en SIDA (RD16/0025/0041) and the grant PI17/01518. JB is a researcher from Fundació Institut de Recerca en Ciències de la Salut Germans Trias i Pujol supported by the Health Department of the Catalan Government (Generalitat de Catalunya).

11. Negredo E, Massanella M, Puertas MC, Buzón MJ, Puig J, Pérez-Alvárez N, et al. Early but limited effects of raltegravir intensification on CD4 T cell reconstitution in HIV-infected patients with an immunodiscordant response to antiretroviral therapy. J Antimicrob Chemother. (2013) 68:2358-62. doi: $10.1093 / \mathrm{jac} / \mathrm{dkt} 183$

12. Massanella M, Negredo E, Puig J, Puertas MC, Buzón MJ, Pérez-Álvarez N, et al. Raltegravir intensification shows differing effects on CD8 and CD4 T cells in HIV infected HAART-supressed individuals with poor CD4 T-cell recovery. AIDS (2012) 26:2285-93. doi: 10.1097/QAD.0b013e328359f20f

13. Llibre JM, Buzón MJ, Massanella M, Esteve A, Dahl V, Puertas MC, et al. Treatment intensification with raltegravir in subjects with sustained HIV1 viraemia suppression: a randomized 48-week study. Antivir Ther. (2012) 17:355-64. doi: 10.3851/IMP1917

14. Negredo E, Back D, Blanco J-R, Blanco J, Erlandson KM, Garolera M, et al. Aging in HIV-Infected Subjects: a new scenario and a new view. Biomed Res Int. (2017) 2017:5897298. doi: 10.1155/2017/5897298

15. Darcis G, Das AT, Berkhout B. Tackling HIV persistence: pharmacological versus CRISPR-based shock strategies. Viruses (2018) 10:E157. doi: $10.3390 / \mathrm{v} 10040157$

16. Massanella M, Fromentin R, Chomont N. Residual inflammation and viral reservoirs: alliance against an HIV cure. Curr Opin HIV AIDS (2016) 11:234-41. doi: 10.1097/COH.0000000000000230

17. Chomont N, El-Far M, Ancuta P, Trautmann L, Procopio FA, YassineDiab B, et al. HIV reservoir size and persistence are driven by $\mathrm{T}$ cell survival and homeostatic proliferation. Nat Med. (2009) 15:893-900. doi: $10.1038 / \mathrm{nm} .1972$

18. Sereti I, Dunham RM, Spritzler J, Aga E, Proschan MA, Medvik K, et al. IL-7 administration drives T cell-cycle entry and expansion in HIV-1 infection. Blood (2009) 113:6304-4. doi: 10.1182/blood-2008-10-186601

19. Gianella S, Anderson CM, Var SR, Oliveira MF, Lada SM, Vargas MV, et al. Replication of human herpesviruses is associated with higher HIV DNA levels during antiretroviral therapy started at early phases of HIV infection. J Virol. (2016) 90:3944-52. doi: 10.1128/JVI.02638-15

20. Haworth KG, Schefter LE, Norgaard ZK, Ironside C, Adair JE, Kiem $\mathrm{H}-\mathrm{P}$. HIV infection results in clonal expansions containing integrations within pathogenesis-related biological pathways. JCI Insight (2018) 3:99127. doi: 10.1172/jci.insight.99127 
21. Dahabieh MS, Battivelli E, Verdin E. Understanding HIV latency: the road to an HIV cure. Annu Rev Med. (2015) 66:407-21. doi: 10.1146/annurev-med-092112-152941

22. Shan L, Deng K, Shroff NS, Durand CM, Rabi SA, Yang H-C, et al. Stimulation of HIV-1-specific cytolytic T lymphocytes facilitates elimination of latent viral reservoir after virus reactivation. Immunity (2012) 36:491-501. doi: 10.1016/j.immuni.2012.01.014

23. Deng K, Pertea M, Rongvaux A, Wang L, Durand CM, Ghiaur G, et al. Broad CTL response is required to clear latent HIV-1 due to dominance of escape mutations. Nature (2015) 517:381-5. doi: 10.1038/nature14053

24. Huang SH, Ren Y, Thomas AS, Chan D, Mueller S, Ward AR, et al. Latent HIV reservoirs exhibit inherent resistance to elimination by $\mathrm{CD} 8+\mathrm{T}$ cells. J Clin Invest. (2018) 128:876-89. doi: 10.1172/JCI97555

25. Carrillo J, Negredo E, Puig J, Molinos-Albert LM, Rodríguez de la Concepción ML, Curriu M, et al. Memory B cell dysregulation in HIV-1-infected individuals. AIDS (2018) 32:149-60. doi: 10.1097/QAD.0000000000001686

26. Jost $\mathrm{S}$, Altfeld M. Evasion from NK cell-mediated immune responses by HIV-1. Microbes Infect. (2012) 14:904-15. doi: 10.1016/j.micinf.2012.05.001

27. Marras F, Casablanco A, Bozzano F, Ascierto ML, Orlandi C, Di Biagio A, et al. Control of the HIV-1 DNA reservoir is associated in vivo and in vitro with $\mathrm{NKp} 46 / \mathrm{NKp} 30$ (CD335 CD337) inducibility and interferon gamma production by transcriptionally unique NK cells. J Virol. (2017) 91:e00647-17. doi: 10.1128/JVI.00647-17

28. Yue FY, Cohen JC, Ho M, Rahman AK, Liu J, Mujib S, et al. HIVspecific granzyme B-secreting but not gamma interferon-secreting T Cells are associated with reduced viral reservoirs in early HIV infection. J Virol. (2017) 91:e02233-16. doi: 10.1128/JVI.02233-16

29. Chun T-W, Justement JS, Pandya P, Hallahan CW, McLaughlin M, Liu S, et al. Relationship between the size of the human immunodeficiency virus type 1 (HIV-1) reservoir in peripheral blood CD4 $+\mathrm{T}$ cells and CD4 $+: \mathrm{CD} 8+\mathrm{T}$ cell ratios in aviremic HIV-1-infected individuals receiving longterm highly active antiretroviral therapy. J Infect Dis. (2002) 185:1672-6. doi: $10.1086 / 340521$

30. Thorlund K, Horwitz MS, Fife BT, Lester R, Cameron DW. Landscape review of current HIV 'kick and kill' cure research - some kicking, not enough killing. BMC Infect Dis. (2017) 17:595. doi: 10.1186/s12879-017-2683-3

31. Bashiri K, Rezaei N, Nasi M, Cossarizza A. The role of latency reversal agents in the cure of HIV: a review of current data. Immunol Lett. (2018) 196:135-9. doi: 10.1016/j.imlet.2018.02.004

32. Rasmussen TA, Tolstrup M, Brinkmann CR, Olesen R, Erikstrup C, Solomon A, et al. Panobinostat, a histone deacetylase inhibitor, for latent-virus reactivation in HIV-infected patients on suppressive antiretroviral therapy: a phase 1/2, single group, clinical trial. Lancet HIV (2014) 1:e13-21. doi: 10.1016/S2352-3018(14)70014-1

33. Søgaard OS, Graversen ME, Leth S, Olesen R, Brinkmann CR, Nissen SK, et al. The depsipeptide romidepsin reverses HIV-1 latency in vivo. PLoS Pathog. (2015) 11:e1005142. doi: 10.1371/journal.ppat.1005142

34. Gutiérrez C, Serrano-Villar S, Madrid-Elena N, Pérez-Elías MJ, Martín ME, Barbas C, et al. Bryostatin-1 for latent virus reactivation in HIVinfected patients on antiretroviral therapy. AIDS (2016) 30:1385-92. doi: 10.1097/QAD.0000000000001064

35. Lehrman G, Hogue IB, Palmer S, Jennings C, Spina CA, Wiegand A, et al. Depletion of latent HIV-1 infection in vivo: a proof-of-concept study. Lancet (2005) 366:549-55. doi: 10.1016/S0140-6736(05)67098-5

36. Elliott JH, Wightman F, Solomon A, Ghneim K, Ahlers J, Cameron MJ, et al. Activation of HIV transcription with short-course vorinostat in HIVinfected patients on suppressive antiretroviral therapy. PLoS Pathog. (2014) 10:e1004473. doi: 10.1371/journal.ppat.1004473

37. Archin NM, Kirchherr JL, Sung JA, Clutton G, Sholtis K, Xu Y, et al. Interval dosing with the HDAC inhibitor vorinostat effectively reverses HIV latency. J Clin Inves.t (2017) 127:3126-35. doi: 10.1172/JCI92684

38. Elliott JH, McMahon JH, Chang CC, Lee SA, Hartogensis W, Bumpus N, et al. Short-term administration of disulfiram for reversal of latent HIV infection: a phase 2 dose-escalation study. Lancet HIV (2015) 2:e520-9. doi: 10.1016/S2352-3018(15)00226-X

39. Mothe B, Brander C. HIV T-cell vaccines. Adv Exp Med Biol. (2018) 1075:31-51. doi: 10.1007/978-981-13-0484-2_2
40. Ferrari G, Haynes BF, Koenig S, Nordstrom JL, Margolis DM, Tomaras GD. Envelope-specific antibodies and antibody-derived molecules for treating and curing HIV infection. Nat Rev Drug Discov. (2016) 15:823-34. doi: 10.1038/nrd.2016.173

41. Moore PL. The neutralizing antibody response to the HIV-1 env protein. Curr HIV Res. (2018) 16:21-8. doi: 10.2174/1570162X15666171124122044

42. Wu X, Yang Z-Y, Li Y, Hogerkorp C-M, Schief WR, Seaman MS, et al. Rational design of envelope identifies broadly neutralizing human monoclonal antibodies to HIV-1. Science (2010) 329:856-61. doi: $10.1126 /$ science. 1187659

43. Acharya P, Lusvarghi S, Bewley CA, Kwong PD. HIV-1 gp120 as a therapeutic target: navigating a moving labyrinth. Expert Opin Ther Targets (2015) 19:765-83. doi: 10.1517/14728222.2015.1010513

44. Kong R, Xu K, Zhou T, Acharya P, Lemmin T, Liu K, et al. Fusion peptide of HIV-1 as a site of vulnerability to neutralizing antibody. Science (2016) 352:828-33. doi: 10.1126/science.aae 0474

45. Molinos-Albert LM, Clotet B, Blanco J, Carrillo J. Immunologic Insights on the membrane proximal external region: a major human immunodeficiency virus type-1 vaccine target. Front Immunol. (2017) 8:1154. doi: 10.3389/fimmu.2017.01154

46. Jefferis R. Isotype and glycoform selection for antibody therapeutics. Arch Biochem Biophys. (2012) 526:159-66. doi: 10.1016/j.abb.2012.03.021

47. Jefferis R, Lund J, Pound JD. IgG-Fc-mediated effector functions: molecular definition of interaction sites for effector ligands and the role of glycosylation. Immunol Rev. (1998) 163:59-76.

48. Pelegrin M, Naranjo-Gomez M, Piechaczyk M. Antiviral monoclonal antibodies: can they be more than simple neutralizing agents?. Trends Microbiol. (2015) 23:653-65. doi: 10.1016/j.tim.2015.07.005

49. Rerks-Ngarm S, Pitisuttithum P, Nitayaphan S, Kaewkungwal J, Chiu $\mathrm{J}$, Paris R, et al. Vaccination with ALVAC and AIDSVAX to prevent HIV-1 infection in Thailand. N Engl J Med. (2009) 361:2209-20. doi: 10.1056/NEJMoa0908492

50. Kim JH, Excler J-L, Michael NL. Lessons from the RV144 Thai phase III HIV1 vaccine trial and the search for correlates of protection. Annu Rev Med. (2015) 66:423-37. doi: 10.1146/annurev-med-052912-123749

51. Corey L, Gilbert PB, Tomaras GD, Haynes BF, Pantaleo G, Fauci AS. Immune correlates of vaccine protection against HIV-1 acquisition. Sci Transl Med. (2015) 7:310rv7. doi: 10.1126/scitranslmed.aac7732

52. Hessell AJ, Hangartner L, Hunter M, Havenith CEG, Beurskens FJ, Bakker $\mathrm{JM}$, et al. Fc receptor but not complement binding is important in antibody protection against HIV. Nature (2007) 449:101-4. doi: 10.1038/nature06106

53. Bournazos S, Klein F, Pietzsch J, Seaman MS, Nussenzweig MC, Ravetch JV. Broadly neutralizing anti-HIV-1 antibodies require Fc effector functions for in vivo activity. Cell (2014) 158:1243-53. doi: 10.1016/j.cell.2014.08.023

54. Roopenian DC, Akilesh S. FcRn: the neonatal Fc receptor comes of age. Nat Rev Immunol. (2007) 7:715-25. doi: 10.1038/nri2155

55. Martins JP, Kennedy PJ, Santos HA, Barrias C, Sarmento B. A comprehensive review of the neonatal $F_{c}$ receptor and its application in drug delivery. Pharmacol Ther. (2016) 161:22-39. doi: 10.1016/j.pharmthera.2016.03.007

56. Ko S-Y, Pegu A, Rudicell RS, Yang Z-Y, Joyce MG, Chen X, et al. Enhanced neonatal Fc receptor function improves protection against primate SHIV infection. Nature (2014) 514:642-5. doi: 10.1038/nature13612

57. Nishimura Y, Gautam R, Chun T-W, Sadjadpour R, Foulds KE, Shingai M, et al. Early antibody therapy can induce long-lasting immunity to SHIV. Nature (2017) 543:559-63. doi: 10.1038/nature21435

58. McCoy LE, Weiss RA. Neutralizing antibodies to HIV-1 induced by immunization. J Exp Med. (2013) 210:209-23. doi: 10.1084/jem.20121827

59. Trkola A, Purtscher M, Muster T, Ballaun C, Buchacher A, Sullivan N, et al. Human monoclonal antibody $2 \mathrm{G} 12$ defines a distinctive neutralization epitope on the gp120 glycoprotein of human immunodeficiency virus type 1 . J Virol. (1996) 70:1100-8.

60. Muster T, Steindl F, Purtscher M, Trkola A, Klima A, Himmler G, et al. A conserved neutralizing epitope on gp41 of human immunodeficiency virus type 1. J Virol. (1993) 67:6642-7.

61. Tiller T, Meffre E, Yurasov S, Tsuiji M, Nussenzweig MC, Wardemann H. Efficient generation of monoclonal antibodies from single human B cells by single cell RT-PCR and expression vector cloning. J Immunol Methods (2008) 329:112-24. doi: 10.1016/j.jim.2007.09.017 
62. Gaebler C, Gruell H, Velinzon K, Scheid JF, Nussenzweig MC, Klein F. Isolation of HIV-1-reactive antibodies using cell surface-

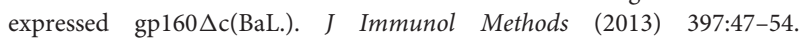
doi: 10.1016/j.jim.2013.09.003

63. Shingai M, Nishimura Y, Klein F, Mouquet H, Donau OK, Plishka $\mathrm{R}$, et al. Antibody-mediated immunotherapy of macaques chronically infected with SHIV suppresses viraemia. Nature (2013) 503:277-80. doi: 10.1038/nature12746

64. Rudicell RS, Kwon YD, Ko S-Y, Pegu A, Louder MK, Georgiev IS, et al. Enhanced potency of a broadly neutralizing HIV-1 antibody in vitro improves protection against lentiviral infection in vivo. J Virol. (2014) 88:12669-82. doi: 10.1128/JVI.02213-14

65. Huang J, Ofek G, Laub L, Louder MK, Doria-Rose NA, Longo NS, et al.. Broad and potent neutralization of HIV-1 by a gp41-specific human antibody. Nature (2012) 491:406-12. doi: 10.1038/nature11544

66. Huang J, Kang BH, Ishida E, Zhou T, Griesman T, Sheng Z, et al.. Identification of a CD4-binding-site antibody to HIV that evolved near-pan neutralization breadth. Immunity (2016) 45:1108-21. doi: 10.1016/j.immuni.2016.10.027

67. Pejchal R, Walker LM, Stanfield RL, Phogat SK, Koff WC, Poignard P, et al. Structure and function of broadly reactive antibody PG16 reveal an H3 subdomain that mediates potent neutralization of HIV-1. Proc Natl Acad Sci USA. (2010) 107:11483-8. doi: 10.1073/pnas.1004600107

68. Mouquet H, Scharf L, Euler Z, Liu Y, Eden C, Scheid JF, et al. Complex-type $\mathrm{N}$-glycan recognition by potent broadly neutralizing HIV antibodies. Proc Natl Acad Sci USA. (2012) 109:E3268-77. doi: 10.1073/pnas.1217207109

69. Lynch RM, Boritz E, Coates EE, DeZure A, Madden P, Costner P, et al. Virologic effects of broadly neutralizing antibody VRC01 administration during chronic HIV-1 infection. Sci Transl Med. (2015) 7:319ra206. doi: $10.1126 /$ scitranslmed.aad5752

70. Caskey M, Klein F, Lorenzi JCC, Seaman MS, West AP, Buckley N, et al. Viraemia suppressed in HIV-1-infected humans by broadly neutralizing antibody 3BNC117. Nature (2015) 522:48-791. doi: 10.1038/nature14411

71. Caskey M, Schoofs T, Gruell H, Settler A, Karagounis T, Kreider EF, et al. Antibody 10-1074 suppresses viremia in HIV-1-infected individuals. Nat Med. (2017) 23:185-91. doi: 10.1038/nm.4268

72. Scheid JF, Horwitz JA, Bar-On Y, Kreider EF, Lu C-L, Lorenzi JCC, et al. HIV1 antibody 3BNC117 suppresses viral rebound in humans during treatment interruption. Nature (2016) 535:556-60. doi: 10.1038/nature18929

73. Liu H, Ponniah G, Zhang H-M, Nowak C, Neill A, Gonzalez-Lopez N, et al. In vitro and in vivo modifications of recombinant and human $\mathrm{IgG}$ antibodies. MAbs (2014) 6:1145-54. doi: 10.4161/mabs.29883

74. Huang Y, Yu J, Lanzi A, Yao X, Andrews CD, Tsai L, et al. Engineered bispecific antibodies with exquisite HIV-1-neutralizing activity. Cell (2016) 165:1621-31. doi: 10.1016/j.cell.2016.05.024

75. Bournazos S, Gazumyan A, Seaman MS, Nussenzweig MC, Ravetch JV. Bispecific Anti-HIV-1 antibodies with enhanced breadth and potency. Cell (2016) 165:1609-20. doi: 10.1016/j.cell.2016.04.050

76. Gardner MR, Kattenhorn LM, Kondur HR, von Schaewen M, Dorfman T, Chiang JJ, et al. AAV-expressed eCD4-Ig provides durable protection from multiple SHIV challenges. Nature (2015) 519:87-91. doi: $10.1038 /$ nature 14264

77. Davis-Gardner ME, Gardner MR, Alfant B, Farzan M. eCD4-Ig promotes ADCC activity of sera from HIV-1-infected patients. PLoS Pathog. (2017) 13:e1006786. doi: 10.1371/journal.ppat.1006786

78. Xu L, Pegu A, Rao E, Doria-Rose N, Beninga J, McKee K, et al. Trispecific broadly neutralizing HIV antibodies mediate potent SHIV protection in macaques. Science (2017) 358:85-90. doi: 10.1126/science.aan8630

79. Diskin R, Scheid JF, Marcovecchio PM, West AP, Klein F, Gao $\mathrm{H}$, et al. Increasing the potency and breadth of an HIV antibody by using structure-based rational design. Science (2011) 334:1289-93. doi: $10.1126 /$ science. 1213782

80. Forthal DN, Gach JS, Landucci G, Jez J, Strasser R, Kunert R, Steinkellner $\mathrm{H}$. Fc-glycosylation influences $\mathrm{Fc} \gamma$ receptor binding and cell-mediated antiHIV activity of monoclonal antibody 2G12. J Immunol. (2010) 185:6876-82. doi: 10.4049/jimmunol.1002600

81. Loos A, Gach JS, Hackl T, Maresch D, Henkel T, Porodko A, et al. Glycan modulation and sulfoengineering of anti-HIV-1 monoclonal antibody PG9 in plants. Proc Natl Acad Sci USA. (2015) 112:12675-80. doi: 10.1073/pnas.1509090112

82. Bardhi A, Wu Y, Chen W, Li W, Zhu Z, Zheng JH, et al. Potent in vivo NK cell-mediated elimination of HIV-1-infected cells mobilized by a gp120bispecific and hexavalent broadly neutralizing fusion protein. J Virol. (2017) 91:e00937-1. doi: 10.1128/JVI.00937-17

83. Gautam R, Nishimura Y, Gaughan N, Gazumyan A, Schoofs T, BucklerWhite A, et al. A single injection of crystallizable fragment domain-modified antibodies elicits durable protection from SHIV infection. Nat Med. (2018) 24:610-6. doi: 10.1038/s41591-018-0001-2

84. Pishko A, Nasta SD. The role of novel immunotherapies in non-Hodgkin lymphoma. Transl Cancer Res. (2017) 6:93-103. doi: 10.21037/tcr.2017.01.08

85. Pegu A, Asokan M, Wu L, Wang K, Hataye J, Casazza JP, et al. Activation and lysis of human CD4 cells latently infected with HIV-1. Nat Commun. (2015) 6:8447. doi: $10.1038 /$ ncomms 9447

86. Sung JAM, Pickeral J, Liu L, Stanfield-Oakley SA, Lam C-YK, Garrido C, et al. Dual-affinity re-targeting proteins direct $\mathrm{T}$ cell-mediated cytolysis of latently HIV-infected cells. J Clin Invest. (2015) 125:4077-90. doi: 10.1172/JCI82314

87. Jacobson JM, Colman N, Ostrow NA, Simson RW, Tomesch D, Marlin $\mathrm{L}$, et al. Passive immunotherapy in the treatment of advanced human immunodeficiency virus infection. J Infect Dis. (1993) 168:298-305.

88. Armbruster C, Stiegler GM, Vcelar BA, Jäger W, Michael NL, Vetter N, Katinger HW. A phase I trial with two human monoclonal antibodies (hMAb 2F5, 2G12) against HIV-1. AIDS (2002) 16:227-33.

89. Armbruster C, Stiegler GM, Vcelar BA, Jäger W, Köller U, Jilch R, et al. Passive immunization with the anti-HIV-1 human monoclonal antibody (hMAb) 4E10 and the hMAb combination 4E10/2F5/2G12. J Antimicrob Chemother. (2004) 54:915-20. doi: 10.1093/jac/dkh428

90. Trkola A, Kuster H, Rusert P, Joos B, Fischer M, Leemann C, et al. Delay of HIV-1 rebound after cessation of antiretroviral therapy through passive transfer of human neutralizing antibodies. Nat Med. (2005) 11:615-22. doi: $10.1038 / \mathrm{nm} 1244$

91. Dufloo J, Bruel T, Schwartz O. HIV-1 cell-to-cell transmission and broadly neutralizing antibodies. Retrovirology (2018) 15:51. doi: 10.1186/s12977-018-0434-1

92. Barouch DH, Whitney JB, Moldt B, Klein F, Oliveira TY, Liu J, et al. Therapeutic efficacy of potent neutralizing HIV-1-specific monoclonal antibodies in SHIV-infected rhesus monkeys. Nature (2013) 503:224-8. doi: $10.1038 /$ nature 12744

93. Halper-Stromberg A, Lu C-L, Klein F, Horwitz JA, Bournazos S, Nogueira $\mathrm{L}$, et al. Broadly neutralizing antibodies and viral inducers decrease rebound from HIV-1 latent reservoirs in humanized mice. Cell (2014) 158:989-99. doi: 10.1016/j.cell.2014.07.043

94. Pegu A, Hessell AJ, Mascola JR, Haigwood N. Use of broadly neutralizing antibodies for HIV-1 prevention. Immunol Rev. (2017) 275:296-312. doi: 10.1111/imr.12511

95. Klein F, Halper-Stromberg A, Horwitz JA, Gruell H, Scheid JF, Bournazos S, et al. HIV therapy by a combination of broadly neutralizing antibodies in humanized mice. Nature (2012) 492:118-22. doi: 10.1038/nature11604

96. Abela IA, Berlinger L, Schanz M, Reynell L, Günthard HF, Rusert P, Trkola A. Cell-cell transmission enables HIV-1 to evade inhibition by potent CD4bs directed antibodies. PLoS Pathog. (2012) 8:e1002634. doi: 10.1371/journal.ppat.1002634

97. Massanella M, Puigdomènech I, Cabrera C, Fernandez-Figueras MT, Aucher A, Gaibelet G, et al. Antigp41 antibodies fail to block early events of virological synapses but inhibit HIV spread between T cells. AIDS (2009) 23:183-8. doi: 10.1097/QAD.0b013e32831ef1a3

98. Malbec M, Porrot F, Rua R, Horwitz J, Klein F, Halper-Stromberg A, et al. Broadly neutralizing antibodies that inhibit HIV-1 cell to cell transmission. J Exp Med. (2013) 210:2813-21. doi: 10.1084/jem.201 31244

99. Wu X, Guo J, Niu M, An M, Liu L, Wang H, et al. Tandem bispecific neutralizing antibody eliminates HIV-1 infection in humanized mice. J Clin Invest. (2018) 128:2239-51. doi: 10.1172/JCI96764

100. Borducchi E, Abbink P, Nkolola J, Lewis MG, Geleziunas R, and Barouch D. PGT121 combined with GS-9620 delays viral rebound in SHIV-infected rhesus monkeys. In: 25th Conference on Retroviruses and Opportunistic Infections. Boston, MA: CROI Foundation/IAS-USA (2018). p. 26. 
101. Ledgerwood JE, Coates EE, Yamshchikov G, Saunders JG, Holman L, Enama ME, et al. Safety, pharmacokinetics and neutralization of the broadly neutralizing HIV-1 human monoclonal antibody VRC01 in healthy adults. Clin Exp Immunol. (2015) 182:289-301. doi: 10.1111/cei. 12692

102. Gaudinski MR, Coates EE, Houser KV, Chen GL, Yamshchikov G, Saunders JG, et al. Safety and pharmacokinetics of the Fc-modified HIV-1 human monoclonal antibody VRC01LS: a Phase 1 open-label clinical trial in healthy adults. PLoS Med. (2018) 15:e1002493. doi: 10.1371/journal.pmed.1002493

103. Gaudinski MR, Houser KV, Chen G, Rothwell RS, Costner P, Holnan L, Gordon I, Ledgerwood J. A phase I dose-escalation study of monoclonal antibody VRC07-523LS in healthy adults. In: 25th Conference on Retroviruses and Opportunistic Infections. Boston, MA: CROI Foundation/IAS-USA (2018). p. 407.

104. Cohen YZ, Butler A, Levin R, Millard K, Pack M, Belblidia S, Dizon JP, and Caskey M. A phase I trial of the combination of 3BNC117 and 101074 in HIV-uninfected adults. In: 25th Conference on Retroviruses and Opportunistic Infections. Boston, MA: CROI Foundation/IAS-USA (2018). p. 407.

105. Lu C-L, Murakowski DK, Bournazos S, Schoofs T, Sarkar D, HalperStromberg A, et al. Enhanced clearance of HIV-1-infected cells by broadly neutralizing antibodies against HIV-1 in vivo. Science (2016) 352:1001-4. doi: $10.1126 /$ science.aaf1279

106. Gilbert PB, Juraska M, deCamp AC, Karuna S, Edupuganti S, Mgodi N, et al. Basis and statistical design of the passive HIV-1 Antibody Mediated Prevention (AMP) test-of-concept efficacy trials. Stat Commun Infect Dis. (2017) 9:20160001. doi: 10.1515/scid-2016-0001

107. Huang Y, Karuna S, Carpp LN, Reeves D, Pegu A, Seaton K, et al. Modeling cumulative overall prevention efficacy for the VRC01 phase 2b efficacy trials. Hum Vaccin Immunother. (2018) 14:2116-27. doi: 10.1080/21645515.2018.1462640

108. Voronin Y, Jani I, Graham BS, Cunningham CK, Mofenson LM, Musoke $\mathrm{PM}$, et al. Recent progress in immune-based interventions to prevent HIV-1 transmission to children. J Int AIDS Soc. (2017) 20:e25038. doi: 10.1002/jia2.25038

109. Lambert JS, Mofenson LM, Fletcher CV, Moye J, Stiehm ER, Meyer WA, et al. Safety and pharmacokinetics of hyperimmune anti-human immunodeficiency virus (HIV) immunoglobulin administered to HIVinfected pregnant women and their newborns. Pediatric AIDS Clinical Trials Group Protocol 185 Pharmacokinetic Study Group. J Infect Dis. (1997) 175:283-91.

110. Stiehm ER, Lambert JS, Mofenson LM, Bethel J, Whitehouse J, Nugent R, et al. Efficacy of zidovudine and human immunodeficiency virus (HIV) hyperimmune immunoglobulin for reducing perinatal HIV transmission from HIV-infected women with advanced disease: results of Pediatric AIDS Clinical Trials Group protocol 185. J Infect Dis. (1999) 179:567-75. doi: $10.1086 / 314637$

111. Onyango-Makumbi C, Omer SB, Mubiru M, Moulton LH, Nakabiito C, Musoke P, et al. Safety and efficacy of HIV hyperimmune globulin for prevention of mother-to-child HIV transmission in HIV-1-infected pregnant women and their infants in Kampala, Uganda (HIVIGLOB/NVP STUDY). J Acquir Immune Defic Syndr. (2011) 58:399-407. doi: 10.1097/QAI.0b013e31822 f8914

112. Hessell AJ, Jaworski JP, Epson E, Matsuda K, Pandey S, Kahl C, et al. Early short-term treatment with neutralizing human monoclonal antibodies halts SHIV infection in infant macaques. Nat Med. (2016) 22:362-8. doi: $10.1038 / \mathrm{nm} .4063$

113. Cunningham C, McFarland EJ, Capparelli EV, Muresan P, Perlowski C, Valentine M, et al. Safety and pharmacokinetics of a potent AntiHIV monoclonal antibody, VRC01, in HIV-Exposed Newborns. In: 24th Conference on Retroviruses and Opportunistic Infections, Seattle, WA CROI Foundation/IAS-USA (2017). p. 329.

114. Deal CE, Balazs AB. Vectored antibody gene delivery for the prevention or treatment of HIV infection. Curr Opin HIV AIDS (2015) 10:190-7. doi: 10.1097/COH.00000000000 00145

115. Martinez-Navio JM, Fuchs SP, Pedreño-López S, Rakasz EG, Gao G, Desrosiers RC. Host anti-antibody responses following adenoassociated virus-mediated delivery of antibodies against $\mathrm{HIV}$ and SIV in rhesus monkeys. Mol Ther. (2016) 24:76-86. doi: 10.1038/mt. 2015.191

116. Fuchs SP, Desrosiers RC. Promise and problems associated with the use of recombinant AAV for the delivery of anti-HIV antibodies. Mol Ther Methods Clin Dev. (2016) 3:16068. doi: 10.1038/mtm.2016.68

Conflict of Interest Statement: JC, BC, and JB are founders of AlbaJuna Therapeutics, SL. JB and BC received grants from MSD unrelated to this work.

Copyright (c) 2018 Carrillo, Clotet and Blanco. This is an open-access article distributed under the terms of the Creative Commons Attribution License (CC BY). The use, distribution or reproduction in other forums is permitted, provided the original author(s) and the copyright owner(s) are credited and that the original publication in this journal is cited, in accordance with accepted academic practice. No use, distribution or reproduction is permitted which does not comply with these terms. 